\title{
Distribution of the carbonic anhydrase isoenzymes I, II, and VI in the human alimentary tract
}

\author{
S Parkkila, A-K Parkkila, T Juvonen, H Rajaniemi
}

\begin{abstract}
The distribution of carbonic anhydrase isoenzymes I, II, and VI was studied in the human alimentary tract using specific antibodies to human isoenzymes in conjunction with the immunoperoxidase technique to elucidate the physiological role and possible functional interplay of carbonic anhydrases (CAs) in alimentary canal functions. From the isoenzymes studied, CA II was found to be the most widely distributed in the various epithelia throughout the alimentary canal. In addition to the acinar cells of the parotid and submandibular glands and the duodenal Brunner's glands, it was present in the mucosal epithelium of the oesophagus, stomach, duodenum, and colon. The epithelial cells of the hepatic bile ducts, gall bladder, and pancreatic ducts also contained CA II in abundance. In contrast, CA VI was present only in the serous acinar and ductal cells of the parotid and submandibular glands, and CA I in the mucosal epithelium of the colon and the A cells of the pancreatic Langerhans's islets. These results suggest that CA II as a widely distributed isoenzyme in the epithelia of the alimentary canal and CA VI as secreted into saliva, may form a mutually complementary system protecting oesophageal, gastric, and intestinal mucosa from acidity.

(Gut 1994; 35: 646-650)
\end{abstract}

Carbonic anhydrase (EC 4.2.1.1; CA) is a widespread catalyst of the reversible hydration of carbon dioxide and participates in the control of the ion, fluid, and acid base balance in various epithelia. ${ }^{12}$ The enzyme occurs in at least six isoenzymes with different activities and immunological specificities. The best characterised of the isoenzymes are the cytoplasmic forms, CA I, II, and III. ${ }^{3}$ The membrane bound, mitochondrial, and secreted isoenzymes are termed CA IV, V, and VI, respectively. ${ }^{46}$

CA has been detected in several glandular and mucosal epithelia in the mammalian alimentary tract by biochemical ${ }^{278}$ and histochemical methods ${ }^{8-12}$ suggesting that it plays an important part in various gastrointestinal functions. The distribution of the isoenzymes, however, has not been comprehensively elucidated in the human alimentary tract. At present the best known is the location of the cytoplasmic high activity isoenzyme, CA II. By immunohistochemical techniques it has been shown to be present in the parietal cells of the human gastric glands where its function is probably linked to proton secretion. ${ }^{813} \mathrm{CA}$ II has also been located in the gastric, duodenal, and colonic surface epithelia, in the serous acinar and ductal structures of the human salivary glands, and in the pancreatic and bile ducts where it is suggested to supply the secretions with bicarbonate. ${ }^{81+15} \mathrm{CA}$ VI has been shown to be located in the serous acinar cells of the human parotid and submandibular glands and to be secreted at high concentrations into saliva, ${ }^{15}$ but its presence elsewhere in the human alimentary tract has not been studied. Membrane bound CA IV is a component of the apical plasma membrane of several epithelia and participates in the regulation of the bicarbonate concentration in the secretions. ${ }^{16}$ Its location and role, however, in the alimentary canal has not been established.

To achieve a comprehensive view of the physiological role and possible interplay of the different CA isoenzymes in the alimentary canal functions, additional information is needed, in the first place, about their expression in the alimentary tract. This study was undertaken to elucidate the differential location of CA I, II, and VI in the human alimentary tract by isoenzyme specific immunohistochemical examination.

\section{Methods}

\section{ANTI-SERUM SAMPLES}

Polyclonal rabbit antiserum samples to human CA I and II have been produced and characterised by Parkkila et $a l^{17}$ and that to human CA VI by Parkkila et al. ${ }^{18}$ The antiserum samples showed no cross reactivity in immunoblottings. 1718 The rabbit antibodies to porcine glucagon were from Novo Research Institute (Copenhagen, Denmark).

\section{PREPARATION OF TISSUES}

Samples of the human parotid and submandibular glands, oesophagus, stomach, duodenum, colon, liver, gall bladder, and pancreas were obtained together with routine histopathological specimens taken during surgical operations carried out at Oulu University Hospital. Each tissue sample was divided into several small pieces, about $5 \mathrm{~mm}$ thick. The specimens were fixed in Carnoy's fluid (absolute ethanol+chloroform + glacial acetic acid 6:3:1) for six hours, in Bouin's fluid (saturated aqueous picric acid + formaldehyde solution (36-40\%)+glacial acetic acid $15: 5: 1)$ for 18 hours, or in $4 \%$ paraformaldehyde in $0.1 \mathrm{M}$ phosphate buffered saline (PBS) for 18 hours. All fixations were carried out at $4^{\circ} \mathrm{C}$. The samples were then dehydrated, embedded in paraffin wax in a vacuum oven at $58^{\circ} \mathrm{C}$, and sections of $5 \mu \mathrm{m}$ were placed on gelatine coated microscope slides. Carnoy's fluid preserved best the antigenicity of the enzymes and also gave a satisfactory tissue morphology. The secretory

.
. 
granules of the parotid and submandibular glands, however, were not preserved leading to a diffuse staining pattern when compared with the fixations with Bouin's fluid or paraformaldehyde. Bouin's fluid preserved well the tissue morphology and the enzyme antigenicity while 4\% paraformaldehyde destroyed most of the CA I and II antigenicity.

\section{IMMUNOHISTOCHEMISTRY}

The sections were stained using the immunoperoxidase technique. The steps in the staining were (1) Pretreatment of the sections with undiluted swine serum for 40 minutes and rinsing in PBS; (2) Incubation for one hour with the primary rabbit antiserum diluted $1: 100$ in $1 \%$ bovine serum albumin (BSA) in PBS (BSAPBS); (3) Treatment with swine serum for 40 minutes and rinsing in PBS; (4) Incubation for one hour in biotinylated affinity purified swine immunoglobulins to rabbit immunoglobulins (Dakopatts, Copenhagen, Denmark) diluted 1:300 in BSA-PBS; (5) Treatment with swine serum for five minutes and rinsing in PBS; (6) Incubation for 30 minutes in a 1:600 dilution of peroxidase conjugated streptavidin (Dakopatts) in PBS; (7) Incubation for three minutes in 3, $3^{\prime}$ diaminobenzidine tetrahydrochloride (DAB; Fluka, Buchs, Switzerland) $(9 \mathrm{mg}$ DAB in $15 \mathrm{ml} \mathrm{PBS}$ plus $10 \mu \mathrm{l} 30 \% \mathrm{H}_{2} \mathrm{O}_{2}$ ).

The sections were washed in PBS three times for 10 minutes after incubation steps 2,4 , and 6 . All incubations and washings were carried out at room temperature and the sections were finally mounted in Permount (Fisher Scientific, Fair Lawn, NJ). The sections were viewed with a Leitz Aristoplan microscope (Leitz, Wetzlar, Germany) and photographed on black and white negative film (Ägfapan 25 ISO).

\section{Results}

\section{LOCATION OF CA I}

The erythrocytes stained intensely for CA I in all tissues studied. CA I positive staining was also distinct in the non-goblet epithelial cells of the colon (Fig 1A) and the A cells of the pancreatic Langerhans's islets (Fig 1B). The location of CA I in the A cells was confirmed by subjecting serial sections of the pancreas to staining for CA I and glucagon, which showed colocalisation of the proteins (Figs $1 B$ and $C$ ).
LOCATION OF CA II

CA II was, in contrast with CA I, widely distributed in the epithelia throughout the alimentary tract. It was present in the serous acinar cells of the submandibular (Fig 2A) a parotid glands (data not shown) where it was granularly located in the apical portion of the cells. A faint but clear positive staining was also detected in the stratified squamous epithelium of the oesophagus (Fig 2B) while the oesophageal mucous glands failed to stain (Fig 2C). In the stomach, an intense positive staining for CA II was found in the surface epithelial cells (Fig 2D). The parietal cells of the gastric glands also showed a positive staining while the zymogenic cells remained unstained (data not shown). The epithelial cell staining was most intense in the gastric pit areas. CA II was also detected in the epithelium of the duodenum (Fig 2E) and mucous Brunner's glands (data not shown) where the enzyme was located mainly in the basal cytoplasm and the cell nuclei. In the colon, anti-CA II serum showed a distinct cytoplasmic staining in the non-goblet epithelial cells (Fig 2F). CA I and II clearly colocalised to these cells (Figs 1A and $2 \mathrm{~F}$ ), and their staining intensities decreased from the surface towards the base of the crypt of Lieberkühn. In the liver, the most intense staining for CA II was seen in the hepatic bile ducts, and a faint but distinct staining was also found in the hepatocytes (Fig 2G). The epithelial cells of the gall bladder (Fig $2 \mathrm{H}$ ) and the pancreatic ducts (Fig 2I) also contained the enzyme.

\section{LOCATION OF CA VI}

CA VI was detected in the serous acinar cells and demilunes of the human submandibular (Figs $3 \mathrm{~A}$ and $\mathrm{B}$ ) and parotid (Fig $3 \mathrm{C}$ ) glands where the enzyme was located in granules probably representing the secretory granules. Some epithelial cells of the striated ducts also showed a faint staining (Fig 3C). Interestingly, the other tissues studied showed no specific staining for CA VI (Figs 3D-I).

\section{Discussion}

Carbonic anhydrases are present in various epithelia where they catalyse the reversible hydration of metabolic carbon dioxide $\mathrm{CO}_{2}+$ $\mathrm{H}_{2} \mathrm{O} \leftrightarrow \mathrm{H}^{+}+\mathrm{HCO}_{3}{ }^{-}$, and participate in the control of the ion, fluid, and acid base balance. ${ }^{12}$
Figure 1:

Immunohistochemical staining of $C A I(A, B)$ and glucagon $(C)$ in the human colon $(A)$ and pancreas $(B, C)$. In the colon, $C A I$ is found in the epithelial cells locating in the outer part of mucosa $(A)$. In the pancreas, $C A$ I positive staining is present in the A cells of the Langerhans's islets as CA I and glucagon colocalise in the serial sections $(B, C)$. Carnoy's fluid fixation. Original magnifications $(A \times 250 ; B, C \times 500)$.
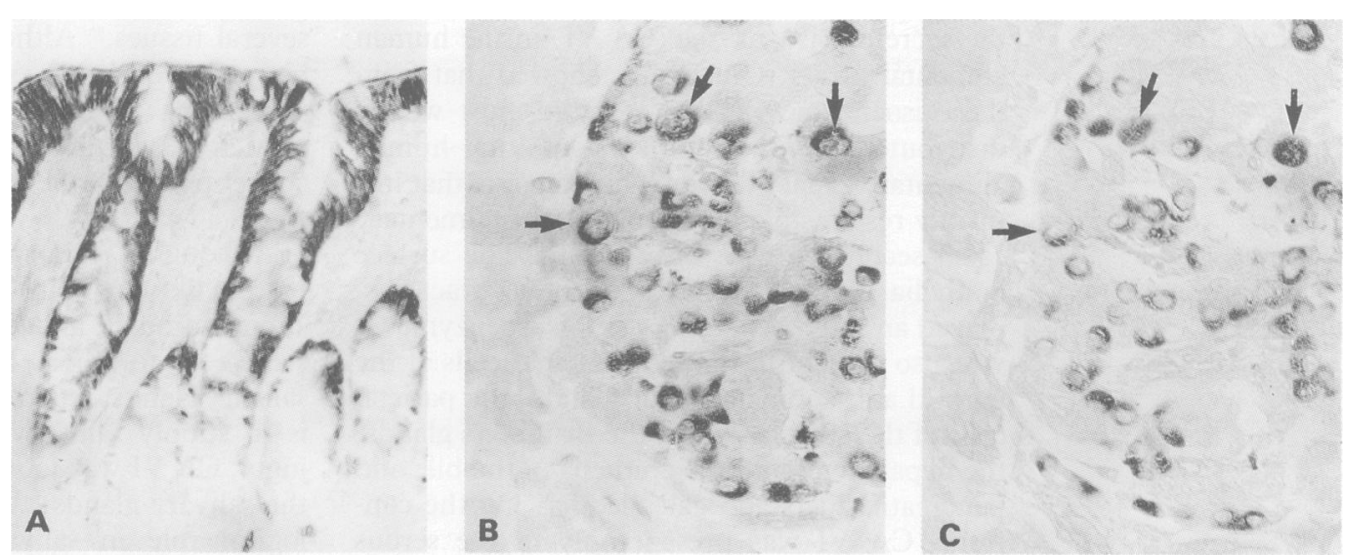
Figure 2:

Immunohistochemical staining of CA II in the human submandibular gland $(A)$, oesophagus $(B, C)$,

stomach $(D)$, duodenum $(E)$, colon $(F)$, liver $(G)$, gall

bladder $(H)$, and pancreas

(I). In the submandibular

gland, the serous acinar cells

show granular staining $(A)$.

The epithelial cells of the

oesophagus are slightly

stained $(B)$ while the mucous

glands failed to stain $(C)$. In

the stomach, the enzyme is

present in the surface

epithelial cells of gastric pits

(D). The surface epithelial

cells show positive staining

both in the duodenum $(E)$

and colon $(F)$. The sections

in Figs $1 A$ and $2 F$ are serial sections. In the liver, the

small $(G)$ and large (insert)

hepatic bile ducts show an

intense positive

immunoreaction and $a$ faint

positive staining is also found

in the hepatocytes. CAII is

also present in the epithelial

cells of the gall bladder $(H)$

and ductal epithelium of the

pancreas (I). Carnoy's fluid

fixation. Original

magnifications $(A, D, F-H \times$

$250 ; B, C \times 500 ; E \times 200$;

$I \times 400)$.
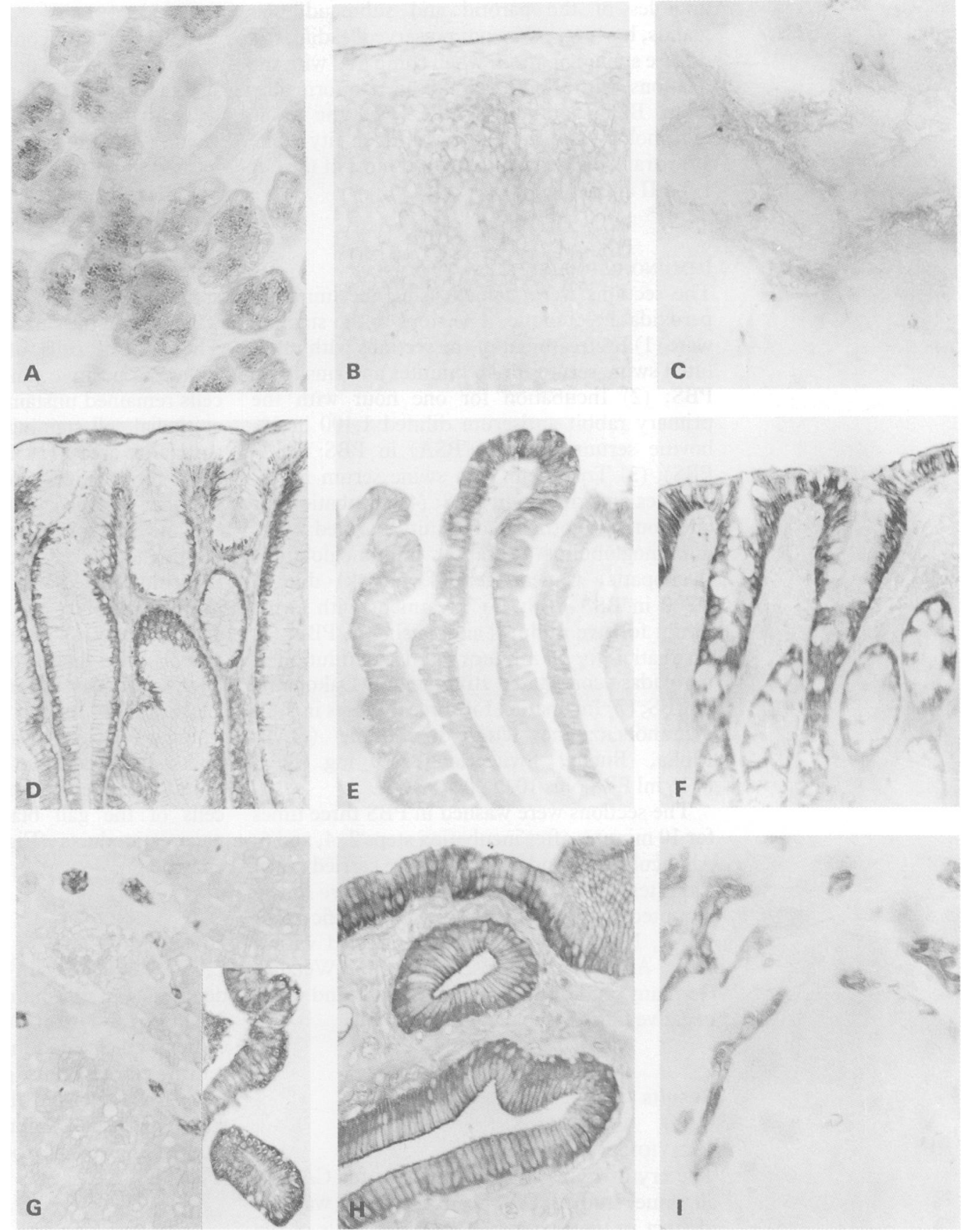

To understand the physiological role and possible interplay of different CA isoenzymes in alimentary canal functions, we studied the differential location of the low activity isoenzyme (CA I), the high activity isoenzyme (CA II), and the secretory isoenzyme (CA VI) in the human alimentary tract. Our results showed that from these isoenzymes, CA II was the most widely distributed in the epithelia of the human alimentary canal (Table). This suggests that it is mainly responsible for supplying the alimentary canal secretions with bicarbonate. The surface epithelia throughout the alimentary tract displayed an intense staining for this isoenzyme. It was also present in the serous acinar cells of the parotid and submandibular glands, the parietal cells of the gastric glands, the Brunner's glands, the hepatocytes and the epithelia of the bile and pancreatic ducts and gall bladder. On the contrary, CA VI was present only in the serous acinar and ductal cells of the parotid and submandibular glands, and CA I in the colonic surface epithelium and the A cells of the Langerhans's islets (Table). CA IV is present in the apical plasma membrane of the epithelial cells of several tissues. ${ }^{16}$ Although its location and role has not yet been established in the human alimentary tract, it is probable that CA IV also participates in the regulation of the bicarbonate concentration of the secretions in the alimentary tract.

Although CA II showed a granular staining pattern like CA VI in the serous acinar cells of the submandibular and parotid glands, it is not secreted into saliva. Thus, its main role in the salivary glands, regardless of its cellular location, is to supply saliva with bicarbonate. Interestingly, CA VI was found to be expressed only in the salivary glands. Although, its exact physiological role in saliva is not yet known, its 
Figure 3:

Immunohistochemical staining of $C A V I$ in the human submandibular $(A, B)$ and parotid glands (C), and in the oesophagus (D), stomach $(E)$, duodenum $(F)$, colon $(G)$, gall bladder $(H)$, and pancreas $(I)$. A positive granular staining is present only in the present only in the
submandibular and parotid glands $(A, B, C)$. The demilunes $(d)$ of the submandibular gland also contain CA VI. A faint staining is also found in some occasional epithelial cells of the striated ducts (arrow). All other tissues are negative All other tissues are negative
(D-I). Paraformaldehyde $(A)$, Bouin's $(B, C)$, and Carnoy's fluid (D-I)

fxations. Original magnifications ( $A, B \times 500$; $C-I \times 250)$.
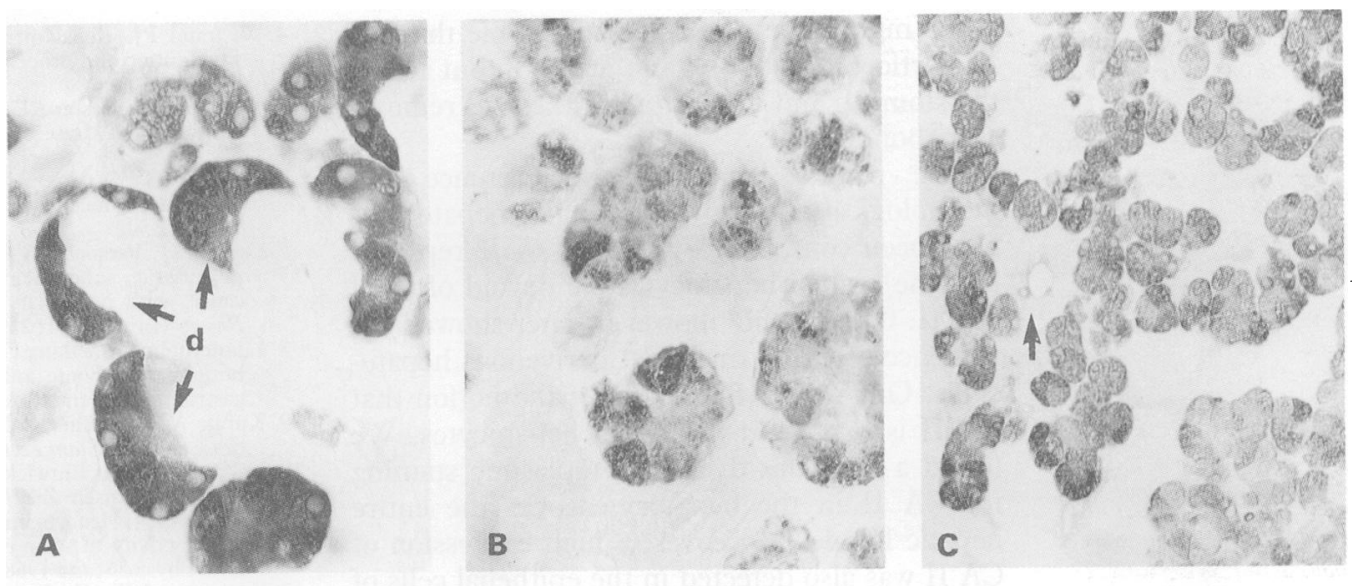

D

E

F

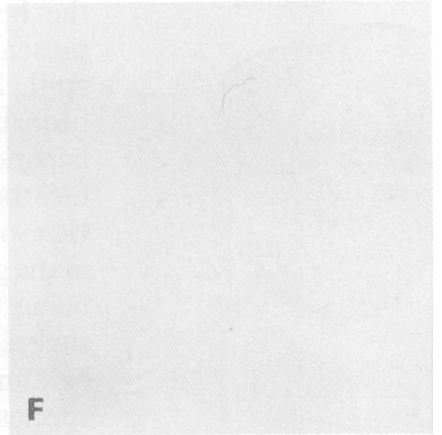

H

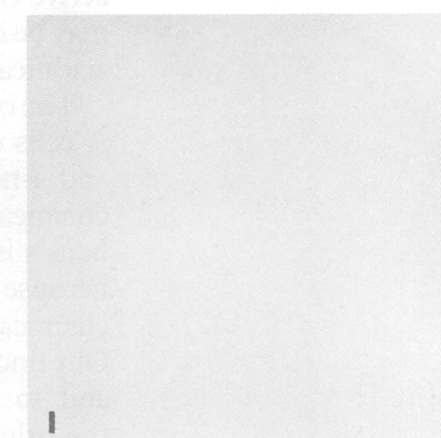

presence there is probably linked to removal of acid as carbon dioxide in the mouth and elsewhere in the alimentary canal by catalysing the reversible reaction $\mathrm{H}^{+}+\mathrm{HCO}_{3} \rightarrow \mathrm{H}_{2} \mathrm{O}+\mathrm{CO}_{2}$. In gastro-oesophageal reflux, the oesophageal mucosa is exposed to acid gastric juice, which

Location of carbonic anhydrase isoenzymes $I, I I$, and VI in the human alimentary tract

\begin{tabular}{|c|c|c|c|c|}
\hline Organs & Histological site & $C A I$ & $C A I I$ & $C A V I$ \\
\hline \multirow[t]{2}{*}{ Parotid gland } & serous cells & - & ++ & $+t+$ \\
\hline & duct cells & - & + & +- \\
\hline \multirow[t]{3}{*}{ Submandibular gland } & serous cells & - & ++ & +++ \\
\hline & mucous cells & - & - & - \\
\hline & duct cells & - & + & +- \\
\hline \multirow[t]{2}{*}{ Oesophagus } & surface epithelial cells & - & + & - \\
\hline & mucous glands & - & - & - \\
\hline \multirow[t]{3}{*}{ Stomach } & surface epithelial cells & - & +++ & - \\
\hline & parietal cells & - & +++ & - \\
\hline & zymogen cells & - & - & - \\
\hline \multirow[t]{2}{*}{ Duodenum } & surface epithelial cells & - & +++ & - \\
\hline & Brunner's glands & - & ++ & - \\
\hline \multirow[t]{2}{*}{ Colon } & surface non-goblet cells & ++ & +++ & - \\
\hline & goblet cells & - & - & - \\
\hline \multirow[t]{2}{*}{ Liver } & hepatocytes & - & + & - \\
\hline & duct cells & - & +++ & - \\
\hline Gall bladder & luminal epithelial cells & - & +++ & - \\
\hline \multirow[t]{3}{*}{ Pancreas } & zymogen cells & - & - & - \\
\hline & islets of Langerhans's (A cells) & ++ & - & - \\
\hline & duct cells & - & +++ & - \\
\hline
\end{tabular}

- , no staining; +- , sporadic stained cells; + , weak staining; ++ , moderate staining; +++ , intense staining. may lead to a severe mucosal damage and oesophagitis. It has been suggested that bicarbonate, both locally produced in the oesophagus and found in swallowed saliva, is an important protective factor in the oesophagus. ${ }^{19}{ }^{20}$ Meyers $e t$ $a l^{21}$ recently reported that the oesophageal mucus contains bicarbonate that is possibly secreted by suggests, however, that bicarbonate is delivered into the oesophageal mucus by the stratified squamous epithelium, which was found to contain CA II.

The gastric mucosa secretes high concentrations of bicarbonate and protons. Bicarbonate ions mainly originate from the surface epithelial cells and protons from parietal cells of the gastric glands that both contain CA II. ${ }^{81314}$ The resistance of the gastric and duodenal mucosa to acid has been proposed to result from a parallel mucus and bicarbonate secretion by the surface epithelial cells. ${ }^{22}{ }^{23}$ The role of CA VI delivered in saliva into stomach and duodenum may also be important in protection of the gastric and duodenal mucosa from acidity. The mean (SD) enzyme content in human saliva is $6.8(4.3) \mu \mathrm{g} /$ $\mathrm{ml}^{24}$ and the daily saliva volume is $1 \cdot 5-2 \cdot 01$. Accordingly, the total amount of CA VI delivered daily in saliva into the stomach is about the oesophageal mucous glands. Our finding here 
10-14 mg. Therefore, it is conceivable that CA VI participates not only in the mouth but also in the stomach and duodenum in the acid removal as carbon dioxide.

The results regarding the presence and physiological role of CA II in the hepatocytes have been contradictory. Spicer $e t a l^{25}$ reported that the human hepatocytes are devoid of CA I and II. Carter et al, ${ }^{26}$ however, later showed the presence of CA II in the rat perivenous hepatocytes. Our results here support the notion that CA II is expressed in human hepatocytes. We found a faint but distinct cytoplasmic staining for CA II in the hepatocytes over the entire hepatic lobule. Moreover, a high expression of CA II was also detected in the epithelial cells of the hepatic bile ducts and gall bladder. The presence of the enzyme in the hepatocytes and epithelial cells of the hepatic bile ducts is probably linked to the alkalinisation of the hepatic bile that may reach concentrations of bicarbonate ions as high as $55 \mathrm{mM}$ in human. ${ }^{22}$ Gleeson $e t a l^{27}$ further reported that $\mathrm{pH}$ is lower in the gall bladder than in hepatic bile, the values being 6.96 and $7 \cdot 3$, respectively. The authors suggested that the human gall bladder epithelium secretes protons, as in several other species. ${ }^{28-31}$ Therefore, the presence of the high active CA II in the epithelium of the gall bladder may be related to proton secretion and thus to the acidification of bile.

The colocalisation of CA I with glucagon in the A cells of the endocrine pancreas is interesting and a novel finding. The earlier positive histochemical reactions for CA activity in the Langerhans's islets ${ }^{32-34}$ have been considered artifactual because the isoenzyme specific immunohistochemical stainings have remained negative..$^{25} 35$ Our finding here seems to solve this discrepancy and to show that the CA activity present in the islets of Langerhans is the low activity isoenzyme, CA I. The A cells seem to be so far the only cell type in the human alimentary tract that expresses specifically CA I but not CA II. It remains, however, to be elucidated its physiological role in the A cell functions.

In summary, the results of this study show that CA II is a widely distributed CA isoenzyme in the human alimentary canal. As the high activity isoenzyme, it probably has a pivotal role in supplying the secretions with bicarbonate throughout in the alimentary tract. We suggest that CA II and secretory CA VI form an important and mutually complementary system protecting the mucosa of the upper alimentary canal from acidity. Thus, a decrease in the expression of CA II or in the secretion of CA VI may lead to reduced protection of mucosa from acidity and to an increased susceptibility to acid peptic diseases.

The authors thank Ms Aino Kuha and Mr Eero Oja for skilful technical assistance. Carter.MJ. Carbonic anhydrase: isoenzymes, properties,
distribution, and functional significance. Biol Rev 1972; 47; 465-513.

2 Maren TH. Carbonic anhydrase: chemistry, physiology, and inhibition. Physiol Rev 1976; 47: 595-781.

3 Tashian RE, Hewett-Emmett $D$, Goodman $M$. On the evolution and genetics of carbonic anhydrases I, II and III. In: Rattazzi MC, Scandalios JG, Whitt GS, eds. Isozymes: current topics in biological and medical research. Vol 7 . New current topics in biological and
4 Wistrand PJ. Renal membrane-bound carbonic anhydrase. Purification and properties. Ups $\mathcal{F}$ Med Sci Suppl 1979; 26: 75.

5 Dodgson SJ, Forster RE, Storey BT, Mela L. Mitochondrial carbonic anhydrase. Proc Natl Acad Sci USA 1980; 77 5562-6.

6 Fernley RT, Wright RD, Coghlan JP. A novel carbonic anhydrase from the ovine parotid gland. FEBS Lett 1979 105: 299-302.

7 Carter MJ, Parsons DS. The isoenzymes of carbonic anhyrase: tissue, subcellular distribution and functional significance, with particular reference to the intestinal tract. $\mathcal{F}$ Physiol (Lond) 1971; 215: 71-94.

8 Lönnerholm G, Selking Ö, Wistrand PJ. Amount and distribution of carbonic anhydrases CA I and CA II in the gastrointestinal tract. Gastroenterology 1985; 88: 1151-61.

9 Kurata Y. Histochemical demonstration of carbonic anhydrase activity. Stain Technol 1953; 28: 231-3.

10 Vollrath L. Über Entwicklung und Function der Belegzellen der Magendrüsen. $Z$ Zellforsch 1959; 50: 36-60.

11 Hansson HPJ. Histochemical demonstration of carbonic anhydrase activity in some epithelia noted for active transport. Acta Physiol Scand 1968; 68 : $1-8$.

12 Korhonen LK, Korhonen E, Hyyppä M. Histochemical demonstration of carbonic anhydrase activity in the alimentary canal. Histochemie 1966; 6: 168-72.

13 Sato A, Spicer SS, Tashian RE. Ultrastructural localization of carbonic anhydrase in gastric parietal cells with the immunoglobulin-enzyme bridge method. Histochem $\mathcal{F} 1980$; 12: 651-9.

14 Kumpulainen $T$. Immunohistochemical localization of human carbonic anhydrase isozymes. Ann N Y Acad Sci 1984; 429 . 359-68.

15 Parkkila S, Kaunisto K, Rajaniemi L, Kumpulainen T, Jokinen K, Rajaniemi H. Immunohistochemical localization of carbonic anhydrase isoenzymes VI, II and I in human parotid and submandibular glands. $\mathcal{F}$ Histochem Cytochem parotid and subman
$1990 ; 38: 941-7$.

16 Zhu XL, Sly WS. Carbonic anhydrase IV from human lung. Purification, characterization, and comparison with membrane carbonic anhydrase from human kidney. $\mathcal{F}$ Biol Chem 1990; 265: 8795-801.

17 Parkkila A-K, Parkkila S, Juvonen T, Rajaniemi H. Carbonic anhydrase isoenzymes II and I are present in the zona glomerulosa cells of the human adrenal gland. Histochemistry 1993; 99: 37-41.

18 Parkkila S, Kaunisto K, Rajaniemi H. Location of the carbonic anhydrase isoenzymes VI and II in human salivary glands by immunohistochemistry. In: Botré $F$, Gros $G$, glands by immunohist genetics to physiology and clinical medicine. Weinheim: VCH genetics to physiology and clinical
Verlagsgesellschaft, 1991: $254-7$.

19 Helm JF, Dodds WJ, Hogan WJ, Soergel KH, Egide MS, Wood CM. Acid neutralizing capacity of human saliva. Gastroenterology 1982; 83: 69-74.

20 Helm JF, Dodds WJ, Pelc LR, Palmer DW, Hogan WJ, Teeter BC. Effect of esophageal emptying and saliva on clearance of acid from the esophagus. N Engl F Med 1984; 310: $284-8$.

21 Meyers RL, Orlando RC. In vivo bicarbonate secretion by human esophagus. Gastroenterology 1992; 103: 1174-8.

22 Swenson ER. Distribution and functions of carbonic anhy drase in the gastrointestinal tract. In: Dodgson SJ, Tashian RE, Gross G, Carter ND, eds. The carbonic anhydrases. Cellular physiology and molecular genetics. 1st ed. New York: Plenum, 1991: 265-87.

23 Flemström G. Gastroduodenal mucosal secretion of bicarbonate and mucus. Physiologic control and stimulation by nate and mucus. Physiologic control and stimula

24 Parkkila S, Parkkila A-K, Vierjoki T, Ståhlberg T, Rajaniemi H. Competitive time-resolved immunofluorometric assay for quantifying carbonic anhydrase VI in human saliva. Clin Chem 1993; 39: 2154-7.

25 Spicer SS, Sens MA, Tashian RE. Immunocytochemical demonstration of carbonic anhydrase in human epithelia cells. F Histochem Cytochem 1982; 30: 864-73.

26 Carter N, Wistrand PJ, Lönnerholm G. Carbonic anhydrase localization to perivenous hepatocytes. Acta Physiol Scand 1989; 135: 163-7.

27 Gleeson D, Hood KA, Murphy GM, Dowling RH. Calcium and carbonate ion concentrations in gallbladder and hepatic bile. Gastroenterology 1992; 102: 1707-16.

28 Whitlock RT, Wheeler HO. Hydrogen ion transport by isolated rabbit gallbladder. Am f Physiol 1969; 217:310-6.

29 Sullivan B, Berndt WD. Transport by isolated rabbit gallbladders in bicarbonate-buffered solutions. Am $\mathcal{F}$ Physiol bladders in bicar
1973; $225: 845-8$

30 Weinman SA, Reuss L. $\mathrm{Na}^{+} / \mathrm{H}^{+}$exchange at the apical membrane of Nectarus gallbladder. Extracellular and intracellular pH studies. F Gen Physiol 1982; 80: 299-321.

31 Rege RV, Moore EW. Evidence for $\mathrm{H}^{*}$ secretion by the in vivo canine gallbladder. Gastroenterology 1987; 92: 281-9.

32 Bleyl U. Zur Spezifität des histochemischen Carboanhydratase-nachweises im Inselorgan der Bauchspeicheldrüse. Histochemie 1964; 4: 286-311.

33 Bleyl U, Mash B. Histochemischer Nachweis der Carboanhydratase in Pankreas und Placenta (Methode am flottierenden Schnitt). Klin Wochenschr 1964; 42: 402-5.

34 Boquist $\mathrm{L}$, Hagström S. Carbonic anhydrase activity in mouse endocrine pancreas. Acta Pathol Microbiol Scand 1979; 87: 157-64.

35 Kumpulainen T, Jalovaara P. Immunohistochemical localization of carbonic anhydrase isoenzymes in the human pancreas. Gastroenterology 1981; 80: 796-9. 